\title{
EFEKTIFITAS STERILISASI METODE OZON DI RUANG PERAWATAN EDELWIS DAN VK BERSALIN RSUD BANYUMAS TAHUN 2016
}

\author{
Fara Destiara $^{1)}$, Tri Cahyono ${ }^{2)}$ \\ Jurusan Kesehatan Lingkungan, Politeknik Kesehatan Kemenkes Semarang, \\ Jl. Raya Baturaden KM 12 Purwokerto, Indonesia
}

\begin{abstract}
Abstrak
Sterilisasi ozon berfungsi mensterilkan alat-alat yang tidak bersekala. Penghancuran bakteri menggunakan sterilisasi ozon terjadi melalui proses oksidasi langsung. Penelitian ini bertujuan untuk mengetahui efektifitas penggunaan sterilisasi metode ozon terhadap angka kuman udara sebelum dan sesudah sterilisasi menggunakan ozon di ruang perawatan RSUD Banyumas. Metode yang digunakan yaitu metode observasional analitik, dengan pendekatan cross sectional yang dilakukan untuk mengetahui penurunan jumlah angka kuman pada ruangan sebelum dan sesudah di sterilisasi. Populasi 2 ruang Edelwis dan 1 ruang VK Bersalin RSUD Banyumas dengan jumlah 6 sampel. Hasil penelitian diketahui bahwa angka kuman di udara ruang Edelwis B3-4 sebelum disterilisasi yaitu $5.000 \mathrm{CFU} / \mathrm{m}^{3}$ dan setelah sterilisasi menjadi $1.000 \mathrm{CFU} / \mathrm{m}^{3}$, Ruang Edelwis B7-8 sebelum sterilisasi yaitu 293.250CFU/ $\mathrm{m}^{3}$ dan setelah sterilisasi menjadi $3.000 \mathrm{CFU} / \mathrm{m}^{3}$, dan Ruang VK Bersalin sebelum sterilisasi yaitu 3.545.250CFU $/ \mathrm{m}^{3}$ dan setelah sterilisasi menjadi $13.250 \mathrm{CFU} / \mathrm{m}^{3}$. Presentase penurunan rata-rata $93 \%$. Hasil analisi diketahui tidak terdapat perbedaan yang signifikan antara angka kuman udara sebelum dan sesudah sterilisasi. Hasil pengukuran suhu pada ruang perawatan rata-rata $28,66^{\circ} \mathrm{C}$, kelembaban $61 \%$, dan pencahayaan 82,66 lux.
\end{abstract}

Kata kunci : Angka kuman, sterilisasi ozon, ruang perawatan

\begin{abstract}
Ozon sterilization is used to sterile non scale instrument. Bacteria disintegration that used ozon sterilization through the direct oksidation process.the purpose of this research to find out The effectiveness of ozon sterilization method in RSUD Banyumas treatment room.The researcher use analitic observational metod with cross sectional approachment, that is used to find out derivation number of microbe before and after sterilization process. there are three treatment rooms, two Edelwis rooms and one VK Bersalin RSUD Banyumas as the population and six sample of this research. As the result, the microbe number in Edelwis B3-4 before sterilization is $5.000 \mathrm{CFU} / \mathrm{m}^{3}$ and become $1.000 \mathrm{CFU} / \mathrm{m}^{3}$ after sterilization. While in Edelwis B7-8 the microbe number before and after sterilization are 293.250CFU/m $\mathrm{m}^{3}$ and $3.000 \mathrm{CFU} / \mathrm{m}^{3}$. last, the microbe number before and after sterlization in VK bersalin are $3.545 .250 \mathrm{CFU} / \mathrm{m}^{3}$ and $13.250 \mathrm{CFU} / \mathrm{m}^{3}$. Thereare no significant difference between the microbe number berfore and after sterilizaton.
\end{abstract}

Keywords $\quad$ : microbe number, ozon sterilization, treatment room.

\section{PENDAHULUAN}

Infeksi nosokomial merupakan suatu infeksi yang diperoleh atau dialami pasien selama dirawat dirumah sakit dan infeksi itu tidak ditemukan atau diderita pada saat pasien masuk rumah sakit. Dirumah sakit dan sarana kesehatan lainnya, infeksi dapat terjadi antar pasien, dari pasien kepetugas, dari petugas ke pasien dan dari petugas ke petugas.

Penghancuran bakteri menggunakan sterilisasi ozon terjadi melalui proses oksidasi langsung. Kekuatan ozon dapat merusak membran sel,dinding bagian luar sel mikroorganisme dan juga dapat membunuhnya. Keuntungan menggunakan ozon yaitu bersifat sinergi ketika ozon direaksikan dengan 1) Email : faradestiara@gmail.com

2) Email : tricahyono37@yahoo.co.id
Sementara kerugiannya gas ozon bersifat toksisk (pada konsentrasi 0,4 ppm), merupakan gas berbau (tercium pada konsentrasi 0,002-0,004 ppm), dapat menyebabkan iritasi saluran pernafasan dan okular (jika terpaparpada konsentrasi 1 ppm selama 24 jam), serta bersifat korosif (Russel et al, 2004,h 30).

RSUD Banyumas merupakan Rumah Sakit negeri kelas B. Rumah Sakit ini mampu memberi pelayanan kedokteran spesialis dan subspesialis terbatas. Rumah Sakit ini juga menampung pelayanan rujukan dari Rumah Sakit Kabupaten, RSUD Banyumas memiliki 414 tempat tidur inap,56 diantaranya merupakan kelas VIP,219 kamar kelas III, lebih banyak dibanding setiap Rumah Sakit di Jawa Tengah yang tersedia rata-rata 56 tempat tidur 
inap. Dengan 55 dokter, perawat 409, tenaga medis 106, serta tenaga administrasi 391.

Ruang edelwis merupakan ruangan yang khusus di gunakan untuk perawatan pasien pasca bedah wanita, ruangan ini merupakan ruangan kelas I dan II. Kelas Iterdiri dari 4 ruangan yang masing-masing ruangan terdiri dari 8 tempat tidur dan untuk kelas II terdiri dari 2 ruang yang di batasi dengan gorden dengan jumlah tempat tidur 16 bed. Dan 1 ruang isolasi, Terdapat 2 kamar mandi yang di lengkapi dengan WC untuk keperluan pasien, 1 ruang admnistrasi dan 1 ruang jaga perawat. Ruang VK (Verlos Kamer) bersalin merupakan ruang pra dan pasca operasi ibu melahirkan, Ruangan ini terletak di depan instalasi gizi dan terhubung dengan ruang Permata Hati. Ruangan ini meliputi : ruang administrasi, ruang perawatan kelas I dan II dan III, ruang jaga bidan, ruang tindakan, ruang isolasi, ruang observasi, kamar mandi dan WC. Ruang Edelwis dan VK bersalin merupakan dua ruangan untuk merawat pasien yang memiliki faktor resiko yang tinggi terkena infeksi nosokimial karena pasien akan atau telah melakukan tindakan medis seperti pembedahan.

Berdasarkan latar belakang tersebut, maka peneliti tertarik untuk mengetahui efektifitas penggunaan sterilisasi metode ozon terhadap angka kuman udara di ruang perawatan RSUD Banyumas. Selanjutnya peneliti bermaksud mengambil judul "Efektifitas Sterilisasi Metode Ozon Udara Di Ruang Perawatan Edelwis dan VK BersalinRSUD Banyumas Tahun 2016”.

\section{METODE PENELITIAN}

Metode yang digunakan yaitu metode observasional analitik, dengan pendekatan cross sectional yang dilakukan untuk mengetahui penurunan jumlah angka kuman pada ruangan sebelum dan sesudah di sterilisasi. Populasi 2 ruang Edelwis dan 1 ruang VK Bersalin RSUD Banyumas dengan jumlah 6 sampel. Pengukuran dilakukan 2 kali yaitu pengukuran sebelum dan sesudah perlakuan. Variabel pengukuran meliputi suhu, kelembaban, pencahayaan, dan volume rungan. Perlakuan yaitu sterilisasi dengan menggunakan alat ozon selama 30 menit. Analisis menggunakan uji Paired T test dengan SPSS 17.0.

\section{HASIL DAN PEMBAHASAN}

Tabel 1 Persentase Penurunan Angka Kuman Sebelum dan Sesudah Sterilisasi

\begin{tabular}{lccc}
\hline \multirow{2}{*}{ Lokasi } & \multirow{2}{*}{ Waktu } & \multicolumn{2}{c}{ Angka kuman $\left(\mathbf{C F U} / \mathbf{m}^{3}\right)$} \\
\cline { 3 - 4 } & & $\begin{array}{c}\text { Sebelum } \\
\text { sterilisasi }\end{array}$ & $\begin{array}{c}\text { Sesudah } \\
\text { sterilisasi }\end{array}$ \\
\hline Edelwis & $16 / 04 / 2016$ & 5.000 & 1.000 \\
B3-4 & & & \\
Edelwis & $23 / 04 / 2016$ & 293.250 & 3.000 \\
B 7-8 & & & \\
VK R -I & $23 / 04 / 2016$ & 3.545 .250 & 13.250 \\
Rata-rata - & 1.281 .167 & 5.750 \\
\hline
\end{tabular}

Dari tabel 1 dapat diketahui hasil uji laboratorium di dapatkan hasil ruang Edelwis B3-4 angka kuman sebelum sterilisasi yaitu $5.000 \mathrm{CFU} / \mathrm{m}^{3}$ dan setelah sterilisasi menjadi $1.000 \mathrm{CFU} / \mathrm{m} 3$, Ruang Edelwis B7-8 sebelum sterilisasi yaitu 293.250 $\mathrm{CFU} / \mathrm{m}^{3}$ dan setelah sterilisasi menjadi 3.000 $\mathrm{CFU} / \mathrm{m}^{3}$. Dan Ruang VK Bersalin sebelum sterilisasi yaitu 3.545.250CFU $/ \mathrm{m}^{3}$ dan setelah sterilisasi menjadi $13.250 \mathrm{CFU} / \mathrm{m}^{3}$.

Tabel 2 Persentase Penurunan Angka Kuman Sebelum dan Sesudah Sterilisasi

\begin{tabular}{|c|c|c|c|c|}
\hline \multirow{2}{*}{ Lokasi } & \multicolumn{4}{|c|}{ Angka kuman } \\
\hline & Waktu & $\begin{array}{l}\text { Sebelum } \\
\text { sterilisasi }\end{array}$ & $\begin{array}{l}\text { esudah } \\
\text { erilisasi }\end{array}$ & penurunan \\
\hline Edelwis & $16 / 04 /$ & 5.000 & 1.000 & $80,00 \%$ \\
\hline B3-4 & 2016 & & & \\
\hline Edelwis & 23 & 293.250 & 3.000 & $98,97 \%$ \\
\hline B 7-8 & /04/2016 & & & \\
\hline VK & 23 /04/ & 3.545 .250 & 13.250 & $99,62 \%$ \\
\hline $\mathrm{R}-\mathrm{I}$ & 2016 & & & \\
\hline Rata-rata & - & 1.281 .167 & 5.750 & $93,00 \%$ \\
\hline
\end{tabular}

Hasil analisi di dapatkan hasil efektifitas penggunaan gas ozon untuk mensterilkan ruang perawatan di RSUD Banyumas yaitu untuk ruang Edelwis B3-4 terdapat penurunan hingga 80\%, untuk ruang Edelwis B7-8 mengalami penurunan sebanyak 98,97\%, dan untuk ruang VK Bersalin mengalami penurunan sebesar $99,62 \%$.

Hasil tabel 1 menunjukan penurunan jumlah angka kuman di ruang Edelwis B3-4 dan B7-8 serta ruang VK Bersalin. Angka kuman di ruang perawatan Edelwis B-3-4 sebelum dilakukan sterilisasi $5.000 \mathrm{CFU} / \mathrm{m}^{3}$ dan sesudah di sterilisasi $1.000 \mathrm{CFU} / \mathrm{m}^{3}$ menunjukan adanya pengurangan sebesar $80 \%$ setelah di sterilisasi menggunakan alat ozon. Angka kuman di ruang perawatan Edelwis B78 sebelum dilakukan sterilisasi $293.250 \mathrm{CFU} / \mathrm{m}^{3}$ dan sesudah di sterilisasi $3.000 \mathrm{CFU} / \mathrm{m}^{3}$ menunjukan adanya pengurangan sebesar 98,8 \% setelah di sterilisasi menggunakan alat ozon. Angka kuman di ruang perawatan VK sebelum dilakukan sterilisasi 3.545.250 CFU $/ \mathrm{m}^{3}$ dan sesudah di sterilisasi 13.250 $\mathrm{CFU} / \mathrm{m}^{3}$ menunjukan adanya pengurangan sebesar 99\% setelah di sterilisasi menggunakan alat ozon.

Hasil analisis terjadi penurunan angka kuman udara sebelum dan sesudah sterilisasi menggunakan ozon, namun hasil angka kuman setelah sterilisasi masih belum memenuhi syarat. Menurut KEPMENKES 1204/MENKES/SK/X/2004 Tentang Persyaratan Kesehatan Lingkungan Rumah Sakit yang menerangkan angka kuman di udara di ruang perawatan 200-500 CFU/m ${ }^{3}$ sementara hasil angka kuman udara setelah sterilisasi dengan ozon di ruang Edelwis B3-4 yaitu $1.000 \mathrm{CFU} / \mathrm{m}^{3}$ sehingga tidak memenuhi syarat, untuk ruang Edelwis B7-8 yaitu $3.000 \mathrm{CFU} / \mathrm{m}^{3}$ sehingga tidak memenuhi syarat. Dan ruang VK Bersalin yaitu 13.250CFU $/ \mathrm{m}^{3}$ tidak memenuhi syarat. 
Pengguanaan alat sterilisasi DSM Aerozon belum efektif dalam menurunkan angka kuman disebabkan ozon merupakan gas yang tidak stabil, akan lenyap dalam beberapa menit, kesulitan dalam mengontrol dosis ozon yang digunakan serta terbatasnya daya jangkau gas terhadap besarnya ruangan yang di sterilisasi. Menurut standar operasional Alat DSM Aerozon hanya di gunakan untuk ruangan maksimal berukuran 3x3 meter. Di perlukan alat sterilisasi ozon yang berukuran lebih besar atau jumlah alat yang di sesuaikan denga volume ruangan, di perlukan dosis yang tepat untuk membunuh mikroorganisme di ruangan serta perlunya alat bantu kipas angin atau fan untuk membantu distribusi gas ozon merata di seluruh ruangan. (Kertawijaya, lyon dan sholihin 1993).

Pengambilan sampel kuman udara di ruang Edelwis dan ruang VK Bersalin dilakukan pada tanggal 16 dan 23 April 2016. Berdasarkan hasil pemeriksaan diperoleh angka kuman udara ruang Edelwis dan ruang VK Bersalin pada tabel 1 menurut hasil perhitungan menggunkan SPSS versi 17.0 dengaan rumus Paired $\mathrm{P}$ Test, diketahui nilai signifikan dari $\alpha(0,05)$, yaitu 0,37 maka Ho diterima, sehingga tidak ada perbedaan yang bermakna antara jumlah angka kuman udara di ruang Edelwis dan ruang VK Bersalin RSUD Banyumas.

Faktor-faktor yang mempengaruhi tidak ada beda jumlah angka kuman udara di ruang Edelwis dan ruang VK Bersalin RSUD Banyumas, antara lain suhu, kelembaban, pencahayaan, volume ruangan, tidak adanya jadwal secara rutin sterilisasi ruangan,serta kurang efektifnya penggunaan alat DSM Aerozon.

\section{SIMPULAN DAN SARAN}

\section{Simpulan}

Berdasarkan penelitian diatas dapat disimpulkan bahwa tidak efektif penggunaan sterilisasi metode ozon di ruang perawatan Edelwis dan VK bersalin RSUD Banyumas.

\section{Saran}

1. Pihak RSUD Banyumas sebaiknya melakukan upaya penurunan angka kuman udara dengan cara teknis maupun non teknis. Secara teknis dapat dilakukan dengan cara pembersihan ruangan minimal 1 minggu 2 kali untuk sterilisasi, desinfeksi dan pembersihan dengan lapuntuk ventilasi.

2. Peneliti laindapat dilanjutkan dengan meneliti dosis dan waktu pemaparan yang efektif untuk menurunkan angka kuman udara menggunakan ozon di ruang perawatan RSUD Banyumas.

\section{DAFTAR PUSTAKA}

Adi. agung ari ,2004, Hubungan Suhu,Kelembaban, Pencahayaan Dan Jumlah Pasien Dengan
Angka Kuman Di Unit Rawat Inap RSUD Banyumas. Undergraduate thesis, Diponegoro University.

Alljabbar April 7, 2008, Dunia Fisika, at https://alljabbar.wordpress.com/diakses pada tanggal 10 Desember 2015 pukul 12:30 WIB.

Darmadi.2008. Infeksi Nosokomial: Problematika dan Pengendaliannya, Salemba Medika. Jakarta

Dwi Arini ,Studi Komparasi Angka Kuman Udara Sebelum Dan Sesudah Didesinfeksi Di Kamar Isolasi Ruang Dahlia RSUD Prof. Dr. Margono Soekarjo, juni 2012, Karya tulis kimia, poltekes kemenkes semarang.

Dwi Ary , Pengaruh Luas Ventilasi Terhadap Kejadian TB Paru Di Wilayah Kerja Puskesmas Sukoharjo Kabupaten Sukoharjo Tahun 2013, Skripsi, Universitas Muhamadiyah Surakarta.

Fatimatuzahroh 2014 Studi Awal Aplikasi Teknologi Ozon untuk Deaktivasi Spora Bacillus Sp. Pada Media Padat. Fakultas Teknik Departemen Teknik Kimia, Universitas Indonesia.

Fitri Annisa dkk, 2014 ,Praktikum Mikrobiologi Dasar : Peralatan, Sterilisasi dan Media Pertumbuhan Mikroba , Fakultas Kesehatan Masyarakat Universitas Mulawarma.

Florence Meliawaty ,2012, Efisiensi Sterilisasi Alat Bedah Mulut melalui Inovasi Oven dengan Ozon dan Infrared, Program Studi Kedokteran Gigi, Universitas Kristen Maranatha

Hakan, K., Sedat, VY, 2007, Ozone Aplication in Fruit and Vegetable Processing, Food Reviews International, vol/no: 23(1), pp. 91106,.

Isyuniarto, A, 2009, Pengaruh Waktu Ozonisasi Terhadap Penurunan Kadar BOD, COD, TSS dan Fosfat pada Limbah Cair Rumah Sakit, Ganendra, vol/no: XII(1), pp. 45-49,.

Jurnal Kesehatan Lingkungan Indonesia Vol. 12 No 1 April 2013, Perbedaan Efektifitas Desinfektan Amnium Kuatener 1\% dengan Fenol 1\% dalam Penurunan Angka Kuman Lantai Ruang Perawatan Di RSU Kardina, Kota Tegal. 
Kertawijaya, dkk . (1993). Kimia lingkungan. Bandung: jurusan kimia FPMIPA IKIP Bandung.

Kowalski, WJ., 1998, Bactericidal Effects of High Airborne Ozone Concentrations on Escherichia coli and Staphylococcus aureus, Ozone Science \& Engineering, vol. 20, pp. 205-221,.

Lanugo Jaya, http://lanugojaya/kualitas-udara-dalamruangan.html?m=1, diakses pada tanggal 22 Juni 2016.

Lathifatul Khusna 2014 .Studi Angka Kuman Udara di Ruang Radiologi Dan Ruang ICU RSUD Banyumas. Karya Tulis Ilmiah .

Michael J, dkk, Dasar-Dasar Mikrobiologi 2, Jakarta, McGraw-Hill Book Company, 1995

Nadhila, Andanis Z., 2012, Pengaruh Waktu Inkubasi dan dosis Ozon pada Disinfeksi Hama bakteri Xanthomo nasoryzae pvoryzae Dengan Kombinasi Proses Ozonasi dan Adsorpsi Dengan Zeolit alam, Skripsi, Departemen Teknik Kimia, Fakultas Teknik, Universitas Indonesia.

Nasihihun Ulwan. http://www.portalstatistik.com/2014/02/paired-sampel-t-testdengan-spss.html?m=1 diakses pada tanggal 21 juni 2016 pukul 11:55 WIB
Nina Febriyanti, dkk, Pengaruh Variasi Waktu Sterilisasi Dengan Sinar Ultra Violet Terhadap Angka Kuman Udara Ruang Operasi RSUD Brigjend Hasan Basri Kandangan Provinsi Kalimantan Selatan Tahun 2014, jurnal

Pedoman Teknis Bangunan Rumah Sakit Ruang Rawat Inap, Direktorat Bina Pelayanan Penunjang Medik Dan Sarana Kesehatan Direktorat Bina Upaya Kesehatan Kementerian Kesehatan Ri Tahun 2012

Purwadi, A, 8 Juli 2004, Rancang Bangun Ozonizer Jinjing dan Manfaatnya, Prosiding PPI Litdas Iptek Nuklir P3TM-Batan Yogyakarta.

Purwandaru widyasunu, 2015, bab 4 Suhu Tekanan Kelembaban Udara Dan Pengaruhnya, at http://www.slidesharenet/purwandaruwidyas unu/bab-4-suhu-tekanan-kelembaban-udaradan-pengaruhnya-thd-tanamandiakses pada tanggal 10 Desember 2015 pukul 12:30 WIB.

Syaiful Bahri, Angka Kuman Udara Ruang Perawatan Bayi Di Rumah Sakit Umum Daerah (RSUD) Dr.H. Soemarno Sosroatmodjo Kuala Kapuas Tahun 2010, Karya Tulis Ilmiah, Politeknik Kesehatan Banjarmasin Jurusan Kesehatan Lingkungan Banjarbaru 